DOI https://doi.org/10.30525/978-9934-588-80-8-2.46

\title{
ТЕХНОЛОГІЇ ФОРМУВАННЯ ЦІННІСНО-СМИСЛОВОЇ СФЕРИ СТУДЕНТІВ-ФІЛОЛОГІВ У ВИЩІЙ ШКОЛІ
}

\author{
Северіна T. М. \\ кандидат педагогічних наук, доцент, \\ професор кафедри іноземних мов \\ Хмельницька гуманітарно-педагогічна академія \\ м. Хмельницький, Украӥна
}

Однією з умов особистісно-професійного розвитку майбутнього вчителя у закладі вищої освіти є формування його ціннісно-смислової сфери. У процесі формування особистості студента-філолога ціннісносмислова сфера постає «центром особистісно-професійної саморегуляції на основі вільного, ціннісно-орієнтованого вибору, що забезпечує дійсну професійно-особистісну самореалізацію, свободу його професійно-особистісного самопрояву» [3, с. 92].

Формування ціннісно-смислової сфери студента полягає у цілеспрямованому впливі на його емоційно-вольову сферу 3 метою гармонізації системи ціннісних орієнтацій та вироблення потреби в особистісному зростанні. Такий підхід характеризується: усвідомленням студентом цінностей свого розвитку; суб'єктивним переживанням та оцінкою власних потенцій як особистості та майбутнього професіонала; формуванням позитивного ставлення до своєї діяльності; прагненням до самовдосконалення та активною реалізацією цього прагнення.

Розвиток ціннісно-смислового потенціалу особистості майбутнього фахівця являє собою нелінійний процес індивідуального пошуку, вибору, творчої інтерпретації, інтеріоризації та практичної актуалізації студентом аксіологічного, світоглядного та культурологічного компонентів освіти [2].

На нашу думку, у процесі становлення основ смислоорієнтаційної та смислорегулятивної діяльності майбутнього фахівця провідними завданнями є: формування системи ціннісних орієнтацій та посилення внутрішньої мотивації особистісно-професійного розвитку студента. Вирішенню визначених завдань сприяє розвиток спрямованості смисложиттєвих орієнтацій студентів, надання пріоритетності цінностям розвитку, підсилення значущості мотивів особистісно-професійного розвитку та самореалізації, розвиток суб'єктності на основі формування ціннісного ставлення до себе, оточуючих та власної діяльності. 
Цілеспрямований навчально-виховний вплив зумовлює трансформації соціально значущих мотивів студентів у їхні стійкі переконання, особистісні ціннісні пріоритети.

Як свідчить практичний досвід, найбільш ефективними технологіями з точки зору формування ціннісно-смислової сфери студентівфілологів, $\epsilon$ такі:

1) ділові ігри - метод активного навчання, який моделює діяльність у спеціально створеній проблемній ситуації, сприяє вирішенню поставлених завдань, формуванню умінь i навичок. При організації роботи зі студентами застосовуються різні модифікації ділових ігор: імітаційні, де майбутні педагоги відтворюють діяльність навчальновиховного закладу, конкретних людей; операційні, що сприяють відпрацюванню конкретних подій, операцій, імітуючи реальність; рольові, для яких розробляється модель, де відображено стратегію поведінки, дій, функцій та обов'язків конкретної людини; психосоціодрама - соціально-психологічний театр, де відпрацьовуються вміння встановлювати позитивний психологічний контакт, змінювати психічний стан іншої людини, відчувати ситуацію. Участь викладача у діловій грі вимагає від нього аналізу і пошуку шляхів розв'язання проблеми, сприяє навчанню, розвитку, дослідженню, консультуванню, формуванню вміння працювати в команді.

2) афірмації - дієвий метод особистісно-професійного розвитку майбутнього педагога, характеристика його особистості, показник відчуттів, віри. Афірмації - стислі вислови, мікропрограми для підсвідомості, здатні притягнути в життя особистості приємних людей, обставини, піднести настрій, поліпшити здоров'я, внутрішню гармонію. Працювати з афірмаціями особистість має кожного дня не менше, ніж десять хвилин, повторюючи про себе і вголос. Робота 3 афірмаціями сприятиме формуванню позитивних рис характеру, досягненню цілей, емоційній стійкості. Для того, щоб розпочати працювати з афірмаціями, студенту необхідно: вивчити, зрозуміти їх для підвищення ефективності; створити власні позитивні афірмації, які для особистості є найбільш енергетично потужними; виділити час i місце для роботи з ними; вірити у дієвість афірмацій.

3) проблемно-рефлексивний полілог. Реалізація його охоплює такі етапи: відшукування i 3'ясування проблем (кожний учасник, не наслідуючи попереднього, структурує проблеми); пропонування ідей, спрямованих на розв'язання конкретних проблем; колективне обговорення ідей. Цей метод забезпечує актуалізацію і розвиток творчих можливостей студента до самостійного осмислення проблем майбутньої діяльності, прийняття інноваційних рішень. 
Отже, у ціннісно-смисловій сфері студентів-філологів відображаються найбільш вагомі для них життєві пріоритети, відповідно до яких відбувається осмислення життєвих подій та вибудовується стратегія життєвої і професійної самореалізації. Становленню основ смислоорієнтаційної та смислорегулятивної діяльності майбутніх фахівців сприяють такі технології, як ділові ігри, афірмації та проблемно-рефлексивний полілог, що здійснюють позитивний влив на формування аксіологічної сфери студентів.

\title{
Література:
}

1. Радчук Г. К. Психологічні засади професійного аксіогенезу особистості. Психологія особистості. 2012. № 1 (3). С. 138-150.

2. Федух I. С. Ціннісно-смисловий аспект оволодіння іноземною мовою студентами ВНЗ. Проблеми сучасної педагогічної освіти. URL: http://science.cfuv.ru/wp-content/uploads/2015/10/111.pdf (дата звернення: 24.09.2020).

3. Ярмакеев И. Э. Моделирование личности современного учителя : ценностно-смысловой аспект. Казань : Изд-во Казан. ун-та, 2004. 424 с.

DOI https://doi.org/10.30525/978-9934-588-80-8-2.47

\section{MEANS OF FORMING STUDENTS' SOCIAL COMPETENCE IN THE PROCESS OF TEACHING FOREIGN LITERATURE}

\author{
Stepanenko O. K. \\ Candidate of Philological Sciences, Associate Professor, \\ Senior Lecturer at the Department of Social and Humanitarian Science \\ Communal Institution of Higher Education «Dnipro Academy \\ of Continuing Education» of Dnipropetrovsk Regional Council \\ Dnipro, Ukraine
}

The aim of the work is to characterize the effective means of forming students' social competence while teaching foreign literature. One of the central tasks of modern education is to ensure the student's social adaptation, his or her adaptation to the real conditions of social life, to the structure of social relations and activities. Socialization is a person's lifelong development while interacting with the environment. This involves the assimilation and reproduction of social norms and cultural values as well as the individual's self-development and self-realization in the society which he 